\title{
急性治療領域において慢性腎不全の患者に対する特別な注意が 必要である一腎障害患者での心筋マーカ一解釈上の注意一
}

高齢者・糖尿病患者の増加によって透析患者および 将来透析に移行しうる慢性腎不全患者が年々増加して いる。米国では，慢性腎不全の患者増は重要な「公衆 衛生学的問題」ととらえ，国立腎臓財団（National Kidney Foundation, NKF）は，慢性腎疾患の診断・治 療に関するガイドラインを作成し，すべての医療関係 スタッフに注意を喚起している1)。腎臓病に関する一般 の理解を高めるために, それまで使っていた「慢性腎不 全 (chronic renal failure)」という語を廃止し，「慢性 腎疾患 (chronic kidney disease, CKD)」と呼ぶことも 提唱しており，最近の英文論文ではこの「CKD」とい う用語が一般的となっている。ちなみに「急性腎不全, (狭義の) 慢性腎不全」も acute kidney failure, chronic kidney failure となり，著者にとって違和感があるが， いずれ本邦においても一般化するかもしれない。

周知のとおり，腎不全は心血管病変の危険因子であ る。慢性腎不全患者, 透析患者の心血管病変の診療に あたる機会はますます増えるであろうが，適切な治療 に関してはまだまだ不明な点が多い。近年，大規模研 究によって多くのevidenceに基づく治療指針が提唱さ れているが，こうした研究の多くは，腎不全・透析患 者は研究対象から除外されていることが多い。本邦の 慢性透析患者の統計調査からも，死因の一位は心血管 病変であり $43.7 \%$ を占めており，心筋梗塞は $7.4 \%$ ，心 血管病変の 2 割弱である2)。慢性腎不全, 透析患者を対 象とした心血管病変の予防・治療法に関する一層の研 究が必要であろう。

さらに, 現在, 入院患者, ICU入室患者のなかで，腎 機能障害を有する患者も増加している。我々の施設で も，ICU 入室患者の約 20\%, CCU 入室患者の約 $40 \%$ が, glomerular filtration rate (GFR) が $60 \mathrm{ml} \cdot \mathrm{min}^{-1}$ 以下の慢性腎不全患者に相当する。今後, 集中治療領 域にあっては，腎不全患者の心血管病変をいかに対処 するかという課題に加えて，慢性腎不全患者特有の診

今号のハイライト関連論文

柴田 泰史, 上田 康晴, 野本 剛史, 他. 心筋マーカー (心 筋トロポニンT, ヒト心臓由来脂肪酸結合蛋白）と腎機能の 関連性について。 日集中医誌 2004; 11: 185-91.
断・治療上の問題点を熟知する必要があるだろう。 柴田らの論文「心筋マーカー（心筋トロポニン T, ヒ 卜心臓由来脂肪酸結合蛋白）と腎機能の関連性につい て」は, 腎障害を有する患者に対する各種心筋傷害マー カーの解釈上の注意を喚起している3)。急性心筋梗塞の 生化学的診断のために, 特異性の高い心筋トロポニン $\mathrm{T}$, ヒト心臓由来脂肪酸結合蛋白などが用いられてい るが,これらは腎臓から排泄されるために腎機能が低 下している患者では, 心筋傷害がなくても血中濃度が 高值を示す可能性がある。柴田らはICUに入室した 患者で, 心筋傷害の可能性がある患者を除外し, 心筋 マーカーである心筋トロポニン T (cardiac troponin $\mathrm{T}, \mathrm{cTn} \mathrm{T}$ ), ヒト心臓由来脂肪酸結合蛋白 (heart-type fatty acid-binding protein, H-FABP) に対する腎機 能の影響を評価した。その結果，H-FABP とblood urea nitrogen $(\mathrm{BUN})$, creatinine $(\mathrm{Cr})$ に有意な正 の相関が, creatinine clearance $(\mathrm{CCr})$ とは有意な 負の相関があることを報告している。特に, CCrが30 $\mathrm{m} l \cdot \mathrm{min}^{-1}$ 以下の症例では $100 \% \mathrm{H}-\mathrm{FABP}$ が陽性となる ことは注目に值する。今後は，腎機能に合わせて基準 值を設定できるように症例数を増やし検討していただ きたい。

Herzog は透析患者での急性心筋梗塞診断における ピットフォールとして, 生化学マーカーが軽度上昇の ときに注意が必要なこと, 急性心筋梗塞の診断に心筋 トロポニンが有用であること, 診断には一点での数值 でなく経時的な増減をみる必要があることを述べてい る4)。透析患者のみならず慢性腎疾患患者でも同様の 注意が必要であることが，柴田らの論文により確認さ れるが，「偽陽性」となる危険と同時に，実際は心筋傷 害があるにもかかわらず「偽陽性」として軽視・無視 される両者の危険があることに留意する必要があろう。

さて，H-FABPに限らず，腎蔵で代謝を受けたり，腎 排泄性の物質は, 腎機能が低下するとともに体内に蓄積 するため, 血中濃度が上昇する。このため腎排泄性の薬 物では投与量を減量したり，投与間隔をあけたりしなく てはならない。検査值を解釈する場合にも同様の注意が 必要であり, 腎機能正常者と同じ基準值，カットオフ 
值を使用すると偽陽性率が高くなる。よく知られてい る検査值にはアミラーゼ, 腫瘍マーカーでは carcinoembryonic antigen (CEA), carcinoma (CA) 19-9, squamous cell carcinoma (SCC), tissue polypeptide antigen（TPA）などがあり, 腎不全では 高值を示す5)。

前述した NKF の統計によると，全人口の約 $5 \%$ が GFR $60 \mathrm{~m} l \cdot \mathrm{min}^{-1} \cdot 1.73 \mathrm{~m}^{-2}$ 以下の慢性腎疾患に相当す るという。我が国の人口に当てはめれば,なんと550万 人もの慢性腎疾患患者が存在することになる。入院患 者, 急性期患者ではこの比率が上昇することも予想さ れるし, 当院腎蔵内科へのコンサルテーションの約7割 は急性・慢性腎不全の診断・治療に関連するものであ る6)。これは, 腎臓病を專門としない医師が腎障害を有 する患者の診療にあたる機会が今後ますます増加する ことを意味しているが, 注意しなくてはならないこと は，こうした患者の多くは腎障害があるとは自覚して いないばかりか, ときに担当医も腎障害の存在を見落 としている可能性があることである。たとえば, 70 歳 女性で, 身長 $155 \mathrm{~cm}$, 体重 $50 \mathrm{~kg}$, 血清 Cr が $1.2 \mathrm{mg}$. $\mathrm{d} l^{-1}$ を示していれば，推定 GFR は $30 \sim 50 \mathrm{ml} \cdot \mathrm{min}^{-1}$. $1.73 \mathrm{~m}^{-2}$ であり，すでに立派な「高度腎不全」である。 研修医ならば「血清 $\mathrm{Cr}$ が $1.2 \mathrm{mg} \cdot \mathrm{d} l^{-1}$ と正常上限なの で, 腎機能は正常か, せいぜい軽度低下くらいだろう」 という判断を下しかねない。

慢性腎疾患であることを診断し，腎不全進行を抑制 し, 腎不全の合併症を軽減し, また原疾患に対する適 切な治療を可能にするために, 前述したNKFガイドラ インは腎臓専門医に限らずすべての医療スタッフの常 識としてもつべき知識をまとめている。米国のガイド ラインではあるが, 今後集中治療領域で慢性腎疾患患 者が増加していくことを考え, 集中治療域のスタッフ が留意すべき点をまとめてみたい。

日常臨床で留意すべき点は，まず担当患者の腎機能 をつねに把握しておくこと, この際, 単に血清 $\mathrm{Cr}$ 值で 評価するのではなく，かならずGFRに換算することが 重要である。

先ほどの例に示すように, 血清 $\mathrm{Cr}$ 值は誤解を招きや すい。NKFのガイドラインでは，こうした危険を考慮 し，「血清 $\mathrm{Cr}$ 值単独で腎機能を評価してはならず，検 査室はGFRに換算した值を併記して報告すべき」とし ている1)。GFR換算は, 必ずしも蓄尿を行って 24 時間 $\mathrm{CCr}$ を測定する必要はない。血清 $\mathrm{Cr}$ と患者の身長, 年 齢から GFR を推測する予測式が数多く提唱されてい る。欧米では Cockcroft 式 ${ }^{7)}$, 最近は Modification of
Diet in Renal Disease (MDRD) 研究の式 8), 本邦で はHorioらの式が有名である9)。我々は日常の診療では Cockcroft式を用いることが多いが，高齢者ではHorio らの式がよいといわれている。

Cockcroft 式は

Ccr $=[(140-$ Age $) \times$ body weight $(\mathrm{kg})] /$ $\left[\mathrm{P}\right.$ creatinine $\left.\left(\mathrm{mg} \cdot \mathrm{d} l^{-1}\right) \times 72\right]$

（女性の場合はこの值の 0.85 倍）

日本腎臓学会が推奨する Horio らの式は

男性 : Ccr $=(-0.065$ age -0.493 BMI +33$)$ $\times$ 体重 $(\mathrm{kg}) / \mathrm{Scr} / 14.4$

女性 : Ccr $=(-0.030$ age -0.216 BMI +21$)$ $\times$ 体重 $(\mathrm{kg}) / \mathrm{Scr} / 14.4$

BMI : body mass index [体重 $(\mathrm{kg}) /$ 身長 $(\mathrm{m})^{2}$ ] Scr : serum Cr

であり,これを前述した 70 歳女性, 身長 $150 \mathrm{~cm}$, 体 重 $50 \mathrm{~kg}$, 血清 Cr $1.2 \mathrm{mg} \cdot \mathrm{d} l^{-1}$ を代入して計算すると, 推定GFRはCockcroft式, Horioらの式でそれぞれ34.4, $40.8 \mathrm{~m} l \cdot \min ^{-1} \cdot 1.73 \mathrm{~m}^{-2}$ となる。

ICU で治療を受ける慢性腎不全患者に対しては, 治 療過程での検査值解釈, 薬物用量の調整に特別な注意 が必要だが, 同時に治療にあたって, 腎機能保護の観 点も求められる。腎予備力が低下している患者では, 急性腎不全を引き起こす種々の要因が, 軽度であって も容易に腎障害を起こしうるからである。この点で, 注意することとして, 脱水・体液量減少を避けること, 腎毒性のある薬物, 特にアミノグリコシド系抗生物質, 造影剂, nonsteroidal anti-inflammatory drugs (NSAIDs)，アンギオテンシン変換酵素阻害薬，アン ギオテンシン受容体拮抗薬の使用に注意することがあ る。アンギオテンシン変換酵素阻害薬や A II受容体拮 抗薬は, 本邦では従来腎障害のある患者では禁忌とま でいわれていたが，近年は腎保護・心保護上，頻用さ れる傾向にあり, 特に腎障害患者では腎不全の進行を 抑制する作用があるため積極的に使用される傾向にあ る。長期的には血清 $\mathrm{Cr}$ が $3 \mathrm{mg} \cdot \mathrm{d} l^{-1}$ 以上であっても使 用を前提に慎重に投与されるべき薬剤であるが，急性 腎不全や慢性腎不全の急性増悪時には減量ないし一時 中止が必要となる。腎障害例に対するアンギオテンシ ン変換酵素阻害薬使用の注意点はすでに米国心臓協会の ガイドラインが公表されているので参照してほしい10)。

以上, 慢性腎不全患者を診療するうえでの検査・治 療上の注意点をまとめたが, 集中治療領域では今後ま すます nephrologist, intensivist, cardiologistの協力 が必要となるだろう。 
小松 康宏*1 林田 憲明*2

*1 聖路加国際病院内科医長

$* 2$ 同 内科部長

（₹ 104-8560＼cjkstart東京都中央区明石町 9-1）

Special attention has to be paid for the patients with chronic kidney disease in critical care: A pitfall in interpretation of cardiac biomarkers in renal insufficiency

Yasuhiro Komatsu ${ }^{* 1}$, Noriaki Hayashida *2

${ }^{* 1}$ Kidney Center, ${ }^{* 2}$ Heart Center, St. Luke's International Hospital 9-1 Akashicho, Chuoku, Tokyo 104-8560, Japan

J Jpn Soc Intensive Care Med 2004; 11: $169 \sim 171$

\section{文献}

1) National Kidney Foundation. K/DOQI Clinical practice guidelines for chronic kidney disease: evaluation, classification, and stratification. Am J Kidney Dis 2002; 39: S1266.

2) 日本透析医学会統計調査委員会. わが国の慢性透析療法の 現況(2002 年 12 月 31 日現在).
3) 柴田泰史, 上田康晴, 野本剛史, 他. 心筋マーカー(心筋卜 ロポニン $\mathrm{T}$, ヒト心臓由来脂肪酸結合蛋白) と腎機能の関連 性について. 日集中医誌 2004; 11: 185-91.

4) Herzog CA. How to Manage the Renal Patient with Coronary Heart Disease: The Agony and the Ecstacy of Opinion-Based Medicine. J Am Soc Nephrol 2003; 14: 2556-72.

5) 安藤亮一. 腎不全・透析における腫瘍マーカーの解釈. 腎 と透析(臨時増刊号) 1997; 43: 785-8.

6) 小松康宏. Critical Care 領域における Consultation Nephrology. ICU と CCU(別冊) 2003; 27: S3.

7) Cockcroft DW, Gault MH. Prediction of creatinine clearance fron serum creatinine. Nephron 1976; 16: 31-41.

8) Levey AS, Bosch JP, Lewis JB, et al. A more accurate method to estimate glomerular filtration rate from serum creatinine: a new prediction equation. Modification of Diet in Renal Disease Study Group. Ann Intern Med 1999; 130: 461-70.

9) Horio M, Orita Y, Manabe S, et al. Formula and nomogram for predicting creatinine clearance from serum creatinine concentration. Clin Exper Nephrol 1997; 1: 110-4.

10) Schoolwerth AC, Sica DA, Ballermann BJ, et al. AHA Scientific Statement. Renal Consideration in Angiotensin Converting Enzyme Inhibitor Therapy. Circulation 2001; 104: 1985-91.

受付日 2004 年 2 月 5 日 採択日 2004 年 3 月 15 日

\section{心臓型脂肪酸結合蛋白と心筋トロポニン一「疑うためのマーカー」と 「決め手のマーカー」一}

ESC/ACC (European Society of Cardiology/American College of Cardiology）の急性心筋梗塞のガイド ラインの改定が 2000 年に発表されたときに, 最も強い インパクトを与えたのは, 急性心筋梗塞の診断基準が まったく新しくなったことであった。急性心筋梗塞の 診断基準の基本的事項として，心筋壊死を表現する生 化学マーカーの有意な変化〔トロポニンの典型的な上 昇とゆるやかな低下，または creatine kinase MB isoenzyme (CKMB) のより急激な上昇と低下」が病 理学的所見とともにあげられ, 心電図変化や胸痛の存在 は付随事項となっている1)。病理学的所見は急性心筋梗

\section{今号のハイライト関連論文}

柴田 泰史, 上田 康晴, 野本 剛史, 他. 心筋マーカー (心 筋トロポニンT，ヒト心臓由来脂肪酸結合蛋白）と腎機能の 関連性について。 日集中医誌 2004; 11: 185-91.
塞の迅速診断に役立つことはないので, 現実には診断の 決め手は生化学マーカーで示された心筋の傷害〜壊死と いうことになる。ここでトロポニンとCKMBが選ばれ たのは，その高い心筋特異性にある2),3) (Fig. 1)。トロ ポニンにはthin filament上でトロポニン複合体を形成 しているトロポニン T, トロポニン I, トロポニンCの 3 種類があるが, トロポニン T とトロポニン I は心筋 と骨格筋で構造が異なるため, 心筋卜ロポニン $\mathrm{T}$ (cardiac troponin $\mathrm{T}, \mathrm{c} \mathrm{Tn} \mathrm{T}$ ), 心筋トロポニン I (cardiac troponin I, cTnI) の測定は心筋傷害の有無〜 程度を直接評価するために臨床応用されている3)。一 方, 昔からなじみのある CKMB は骨格筋の CK の $1 \%$ 未満といわれているので, cTnT, cTnI ぼの絶対的 な心筋特異性はないものの有用性が高いと考えられ る。ただし，ここでいう CKMBは日本でいまだに広 く用いられている免疫阻害法による活性值 (activity: 